58. Jahresversammlung der Schweizerischen Gesellschaft für Dermatologie und Venereologie, 1. und 2. Oktober 1976 in Basel

Dermatologica, 1977;155:218-219

\title{
Eine operative Therapie der Hyperhidrosis axillaris
}

\begin{tabular}{|l|l|l|}
\hline A. & & Elchmann \\
\hline F. & & Ott \\
\hline A. & & Scherrer \\
\hline
\end{tabular}

Dermatologische Universitätsklinik (Direktor: Prof. H. Stork), Zürich

\section{Abstract}

Development and problems connected with the surgical treatment of hyperhidrosis are considered. 32 patients were operated according to the method of Préaux. The results are good, both cosmetically and with regard to the diminution of the excessive sweat production.

A. Eichmann, Dermatologische Universitätsklinik, Gloriastrasse 31, CH-8091 Zürich (Schweiz)

WTabelle I. Röntgentherapie der Hyperhidrosis axillaris (1963-1974). 2×360R; 2,0 Al; 50 kV; $20 \mathrm{~cm}$ FHD

Therapieerfolg nach Meinung

der 66 Patienten

(1/4-l Jahr nach Bestrahlung)

Schlechter -

Unverändert 24

Wenig gebessert

Besser 3

Wesentlich gebessert 16

Sehr gut (normalisiert)

1 Die Arbeit wird in extenso in der Schweizerischen Rundschau für Medizin «Praxis» publiziert. Eichmann/Ott/Scherrer Tabelle II. Operative Therapie der Hyperhidrosis axillaris (nach Préaux) 219

\section{Zusammenfassung}

Die Entwicklung und Problematik der operativen Methode der Hyperhidrosis axillaris wird kurz erläutert. Von 32 Patienten, die wir nach der Methode von Préaux operiert ha-ben, werden die Ergebnisse dargelegt. Die Resultate sind sowohl bezügiich Verminderung der übermässigen Schweissproduktion als auch in kosmetischer Sicht gut. 